\title{
How to implement and apply robust design: insights from industrial practice
}

\section{Krogstie, Lars ; Ebro, Martin ; Howard, Thomas J.}

\section{Published in:}

Total Quality Management and Business Excellence

Link to article, DOI:

$10.1080 / 14783363.2014 .934520$

Publication date:

2015

Document Version

Peer reviewed version

Link back to DTU Orbit

Citation (APA):

Krogstie, L., Ebro, M., \& Howard, T. J. (2015). How to implement and apply robust design: insights from industrial practice. Total Quality Management and Business Excellence, 26(12), 387-1405.

https://doi.org/10.1080/14783363.2014.934520

\section{General rights}

Copyright and moral rights for the publications made accessible in the public portal are retained by the authors and/or other copyright owners and it is a condition of accessing publications that users recognise and abide by the legal requirements associated with these rights.

- Users may download and print one copy of any publication from the public portal for the purpose of private study or research.

- You may not further distribute the material or use it for any profit-making activity or commercial gain

- You may freely distribute the URL identifying the publication in the public portal

If you believe that this document breaches copyright please contact us providing details, and we will remove access to the work immediately and investigate your claim. 


\title{
How to implement and apply Robust Design: Insights from industrial practice
}

\author{
Authors: \\ Lars Krogstie \\ HiG, Gjøvik University College (GuC), Department of Technology and Management \\ NTNU, Norwegian University of Science and Technology, Department of Production and Quality Engineering \\ lars.krogstie@hig.no \\ +4761135100 \\ Martin Ebro \\ Valcon A/S \\ DTU, Technical University of Denmark, Department of Mechanical Engineering; \\ maec@mek.dtu.dk \\ +4561676969 \\ Thomas J. Howard \\ DTU, Technical University of Denmark, Department of Mechanical Engineering; \\ thow@mek.dtu.dk \\ +4550115982
}

\section{Keywords:}

Robust Design, Product Development, Industrial Practice, Management Strategy, Success Factors, Variation, Tolerances, Implementation

\begin{abstract}
Robust Design is a framework for designing products and processes which perform consistently in spite of variations. Although it is well described in literature, research shows limited industrial application. The purpose of this paper is to describe and discuss industrial best-practice on Robust Design. Empirical findings are based on a series of semi-structured interviews with four major engineering companies in Northern Europe. We present why they were motivated to use Robust Design, how it has been implemented and is currently applied. Success-factors for solving implementation challenges are also presented and the experienced effects of adopting it are described. The key findings are: i) Training, roles and responsibilities: All companies have given substantial training to their engineers and have implemented new roles with technical responsibility, ii) Robust Design implementation is
\end{abstract}


context dependent: The four case companies were all successful in using Robust Design but with quite different approaches, depending on e.g. their organisational culture, and iii) Not just management commitment, but also true management competencies in Robust Design are essential for a successful implementation. The paper is aimed at professionals and researchers within the field of engineering design, considering why, if, and how to implement and apply Robust Design in an organisation.

\section{1-Introduction}

The purpose of applying Robust Design (RD) is to reduce the unwanted variation in the functional performance in a product and processes, by designing it to be insensitive to various sources of noise. Insufficient robustness can cause; lack of functionality, reduced product lifetime, and variation in performance as a result of noise, wear and deterioration. Robustness can therefore be expressed as the product's ability to consistently meet customer requirements. Surveys show (Ida Gremyr et al. 2003), (Anna C. Thornton et al. 2000) that the majority of companies consider it to be 'important' that their products operate with low variation in functional performance. However, the same studies also show that only a limited number of these companies actually apply RD. An analysis of the industrial applicability of Robust Design methods by Eifler et al. (2013) showed that the majority of methods were not applicable during the early design stages, where decisions regarding the product concept and architecture are being made. Furthermore Anna C Thornton (2004) argues that "the tools are not being routinely used in industry because they are too complex and the data needed to populate the analyses is not available." However, some companies have overcome the technical and organisational challenges of applying RD as part of their product development process. In detail, the purpose of this paper is to analyse these companies now experiencing the positive effects of Robust Design in order to identify their; $i$ ) motivation to work with RD, ii) implementation strategies for tools, methods, training, metrics etc., the iii) corresponding 
barriers to this process, the iv) success-factors solving those and the $\boldsymbol{v}$ ) experienced effects of applying RD.

Existing RD literature has had a strong focus on the development and description of new methods but has hardly considered the challenging task of communicating and implementing the methods in industry. We aim to provide a list of solutions and results already successfully applied in companies from different industrial segments and countries.

Further content is structured as: Theoretical Background handling perspectives on RD and challenges of implementation. Methodology justifying research methodology and case company selection. In results, the companies’ practice and experiences on RD are described and archetypes of applying $\mathrm{RD}$ are discussed. The Conclusion, presents best-practice recommendations for implementing and applying $\mathrm{RD}$.

\section{2-Theoretical Background}

In order to describe how the four companies have applied Robust Design, we first provide a theoretical background that can be used as a framework for analysis and classification. Implementation of RD in an organisation is not just about the actual tools and methods, but also involves application of design methods and change management. Therefore, we also include a section on change management and organisational implementation of design methods.

\section{1-Traditional understanding of Robust Design}

The traditional understanding of robustness and robust design evolves in parallel from both a pragmatic engineering school represented by Taguchi (1986) and a statistical school Box and Wilson (1951). Different perspectives and controversies were discussed by Nair et al. (1992). Typical differences in their goals on RD application have been to obtain a "working solution" 
and an "optimal solution" respectively (Goh 1993). Altogether, both schools have to a large extent, focused on refining the methods of optimising different systems on their insensitivity to variation (aka noise).

Challenges in teaching and applying Robust Design Methods were addressed in the 80`s and 90’s (Myers et al. 1989), and more recent reviews (Myers et al. 2004) continues to suggest extended research in technical areas as opposed to its industrial adoption which is also seen in Park et al. (2006) and Murphy et al. (2005). A review by Beyer and Sendhoff (2007) leaves the "competition between the schools" aside and concludes "Looking for synergies between the different philosophies in these fields is one promising approach towards a qualitative step in robust optimization”.

\section{2-Emerging understanding of Robust Design}

A more recent, pragmatic understanding of Robust Design has been presented by Matthiassen (1997) proposing robust design principles, that would lead to more robust and reliable designs. This continued with Arvidsson and Gremyr (2008) explaining how Robust Design Methodology (RDM) is more than tools and methods and thereby define it to be "systematic efforts to achieve insensitivity to noise factors". This definition supports the need for a more practical approach on RDM as research has shown several industrial challenges in applying RDM (Ida Gremyr et al. 2003) and its surrounding statistical tools (Bergquist and Albing 2006). Novel research approaches on RDM (Ida Gremyr 2005b) and suggestions on how to operationalise it (Arvidsson et al. 2006) have contributed to demystify RDM towards an extended audience and novel approaches (Johannesson et al. 2013) are gradually complementing existing tools. Proposals have been made on how to integrate RDM in a generic product development process (Hasenkamp et al. 2007); (Anna C Thornton 2004), some industrial insight on implementation is reported (Saitoh et al. 2003a), (Saitoh et al. 
2003b), and research has searched for the practices ("what needs to be done") that joins the RDM-principles with the specific tools (Hasenkamp et al. 2009). Hasenkamp et. Al. also concludes "there is little support in the literature to date that focuses on the continuous application of RDM". Altogether Arvidsson and Gremyr (2008) define the principles of RDM to be based on (i) awareness on variation, (ii) insensitivity to noise, (iii) application of various methods and (iv) continuous application. An extension of RDM towards visual robustness by Forslund and Söderberg (2010) quantifies the effects of variation on users’ product quality perception. A growing acceptance of applying RDM in industry is currently observed (Ida Gremyr and Hasenkamp 2011), recent published books address industrial needs (Bergman et al. 2009), (Arnèr 2014), and remaining difficulties in applying RDM continuously have been met with specific countermeasures suitable for industry. One example is Azadeh Fazl Mashhadi et al. (2013) reporting how a learning alliance between industry and university increased the acceptance on learning and applying RDM in industry. Other approaches of integrating RDM are seen in Parsley et al. (2013).

\subsection{Organisational change within Product Development}

The traditional explanation of product development as a linear and rational process has been supplemented by a more flexible and collaborative approach which has been reported in later years (M Kreimeyer et al. 2006). Yet product development remains a complex and context specific activity and authors tend to emphasise a limited set of facets of Product Development in their research. The collaborative sides of product development have been researched by Poggenpohl (2004) and the designers have been claimed to be among the most important assets of an organisation (Frankenberger et al. 1997). Others see some element of performance measurement and related metrics as needed for success (Robson 2005) and even link it to a "culture of high performance" which has its own body of research (Pentland 2012). Others also see product development success to be dependent on a formalised process where 
different stage-gates need to be passed (Cooper and Kleinschmidt 2007) or by applying a certain methodology (Lindemann 2009) yet with adaptions to the context. Product Development-success is seen as dependent on an integrated workmode that either depends on creating flow (Reinertsen 2009) or understanding the complex nature of Product Development (Matthias Kreimeyer and Lindemann 2011). Organisational changes involving the implementation of new design methods can face barriers, such as reported by Hicks et al. (2009).

Advice on how to implement initiatives in product development organisations does however exist. The literature shows how similar (yet clearly different) initiatives such as Six Sigma principles was brought upstream towards Product Development (Banduelas and Anthony 2003) and how Design for Six Sigma (DFSS) can be implemented (Ericsson et al. 2009 ). As statistical techniques are reported (Bergquist and Albing 2006) to be hard to implement in organisations, quite specific guidelines are proposed to help practitioners apply the methods (Costa et al. 2006). Other research has even seen congruence between the critical success factors of Six Sigma and the antecedents of successful organisational change (Pinedo-Cuenca et al. 2012). Research has also explored how management control impacts the creation of knowledge within Product Development (Richtnér and Åhlström 2010a). Recent research has also explored how soft and hard factors interact in the case of TQM (Calvo-Mora et al. 2013).

\section{Methodology}

Although the uptake of RD in industry is limited, certain companies have successfully implemented it in their development process, which makes it interesting to analyse why and how they have done this. Here we present our approach on empirical data gathering and some central characteristics of the companies.

\section{1-Gathering empirical industrial data}


In order to gain rich and deep impressions of industrial practice on RD we performed a descriptive case study, which represents a description of a past or ongoing phenomenon (Leonard-Barton 1990) drawing on different sources of empirical data. This insight comes from four different well established industrial companies in four different countries developing, manufacturing and selling products for different market segments. One key criterion prior to the selection was that a large degree of both product development and manufacturing should be in-house, which excluded selecting pure product-development companies or stand-alone manufacturing plants.

Company selection was done to gain a balanced picture of various engineering segments and different locations and similar comparisons are found in Davis (2006). Three companies were approached through ongoing research projects on $\mathrm{RD}$ and related topics. One company was approached upon reported activities on RD (Azadeh Fazl Mashhadi et al. 2013). It is not claimed that the four top-performing companies on RD have been selected, but based on years in research, industry, and consulting, the authors are confident that the selected companies can provide relevant insights into the implementation of RDM. Company names have been anonymised due to confidentiality agreements, and replaced with a generic name in this paper, but the titles of the interviewees, all regarded as company experts on Robust Design, are shown in

Figure 1. The companies represent the industrial fields of; medical device industry (MED), defense (DEF), aerospace (AERO), and automotive (AUTO). The motivation was to gain an impression on whether $\mathrm{RDM}$ is applied differently in the companies, as well as their perception on the current content and their challenges and benefits by aiming for designing robust products. 


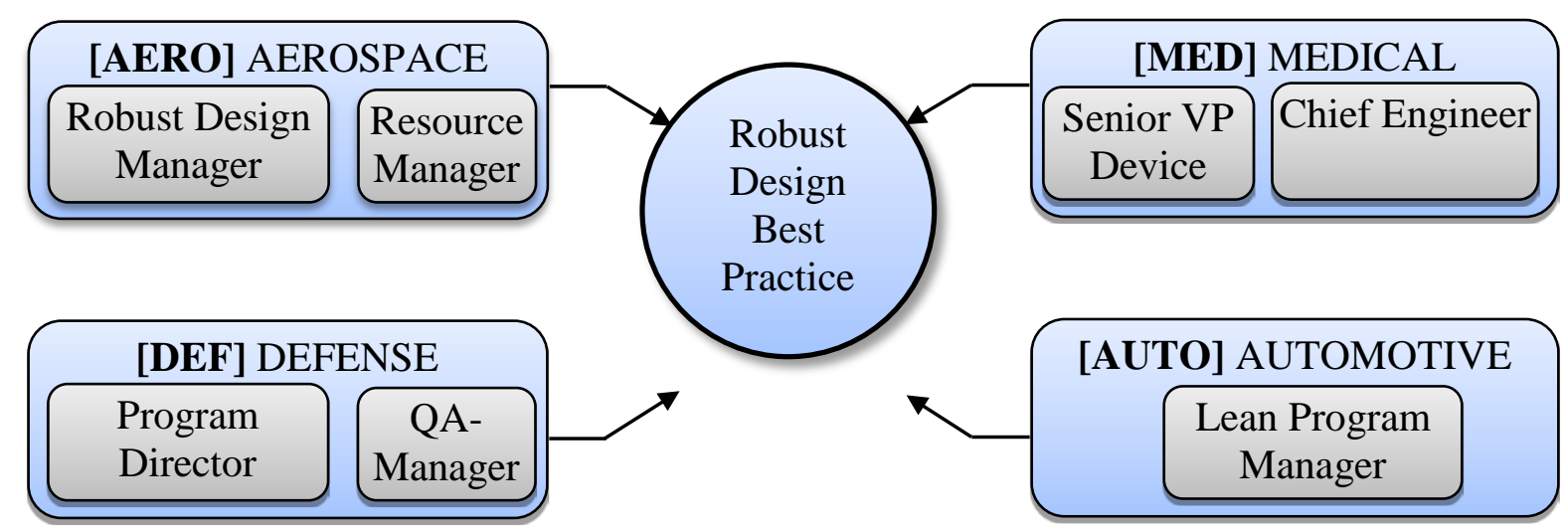

Figure 1 - Interviews were carried out in four companies in four different countries in order to extract findings on Robust Design Best-Practice.

Semi-structured interviews were applied as the means to gather the main set of empirical data. Interviews are accepted to be a strong source of data supporting a deep understanding of a given phenomenon (Yin 2003). An interview guide designed by the researchers was sent out to the interviewee some days prior to the interview. The interview questions revolved around the following core topics: (Q1) Why did you start applying RD (your concept of it/motivation for applying it), (Q2) _ How did you do it (starting point, current position, target for activities, organisation and implementation), (Q3) Challenges (barriers during implementation, application across department borders), (Q4) Countermeasures on challenges and its success factors to face the challenges, (Q5) The effects of Robust Design.

All interviews were kept within one hour in length, according to guidelines for qualitative research (Tjora 2012), recorded digitally, transcribed, and coded after the interview. The approach of interviewing a small sample size of experts as opposed to surveying many novices is recommended by Lai et al. (2006). No prescribed categories were used in the coding process and the RD-archetypes later identified arose from the data during coding and analysis. Research findings were discussed with the participating companies in separate sessions prior to publication. 


\section{2- Case company characteristics}

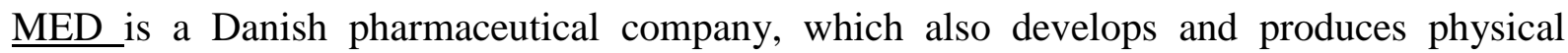
medical devices that the user can use to administer drugs. Production volumes of their devices are typically measured in 'hundred millions pr. year'. Their production and assembly is spread across multiple lines in different locations around the globe. Users are highly dependent on the functionality of the devices, and they have to inject themselves up to several times a day. Injecting a wrong dose could have serious consequences - even lethal. The mechanical engineering department has several hundred employees.

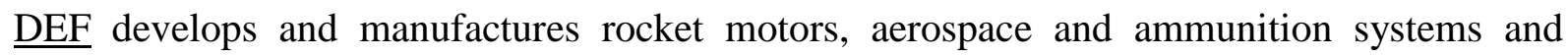
components. The company operates both in the military and civilian market segments. A large part of the development and manufacturing activities related to the researched activities of RD are located in Norway. Its typical products are characterised by high demands on reliability, product performance and precision. The two researched divisions have distinct differences in product volume; one division produces volumes of 'hundreds` whereas the other division produces 'millions'. Altogether the relevant engineering workforce for this study counts approx. one hundred.

$\underline{\mathrm{AERO}}$, is a defence Aerospace Company based primarily in the United Kingdom which develops and produces engines for the aerospace industry. A typical annual volume is measured in 'hundreds'. The customers are the defence departments of various countries. It is costly for AERO to make late-stage design changes, due to the need for re-certification of the engines. Failures in the market can obviously have severe consequences, but also simple failures are costly both to the customer and to AERO due to their service contract commitments. Mechanical product development is spread across several departments and sites, but 'several hundred' engineers have been involved in the RD program. 
$\underline{\text { AUTO }}$ is based in Sweden and develops and produces commercial trucks. The products have a long life-time with a large variation in operating conditions, such as temperature spans, road conditions, use patterns, etc. Customers are highly dependent upon the 'up-time' of the truck and therefore any service on the product results in a relatively large 'cost of non-quality' for the customer. Therefore, the reliability of the truck is a crucial for the brand value. The volume is typically measured in 'thousands', and the markets are spread around the globe. AUTO has several divisions with a total of 'thousands' of mechanical engineers.

In the following result section, interview findings are presented according to Table 1. Differences and similarities in the approaches are presented prior to a description and categorisation of four different strategies for RD implementation. A closing discussion of the applicability of the four different Robust Design-archetypes in different Product Development-contexts is provided.

\begin{tabular}{|l|l|c|c|c|}
\hline TOPIC & \multicolumn{1}{|c|}{ MED } & DEF & AERO & $\begin{array}{c}\text { Sub- } \\
\text { section }\end{array}$ \\
\hline Why (Q1) & What was the motivation for adopting Robust Design? & 4.1 \\
\hline How (Q2) & How was Robust Design implemented? How is it applied today? & 4.2 \\
\hline Challenges (Q3) & What were the challenges in the implementation? & 4.3 \\
\hline Success factors (Q4) & What made the implementation successful? & 4.4 \\
\hline Effects (Q5) & What have been the effects of adopting Robust Design? & \\
\hline Similarities & \multicolumn{2}{|c|}{5.2 c } & 5.2 d & \\
\hline Differences & 5.2 a & 5.2 b & 5.3 & \\
\hline Archetypes & \multicolumn{2}{|c|}{5} & \\
\hline
\end{tabular}

Table 1 - Graphical representation of the structure in the Results and Discussion Sections.

\section{4-Results}

The most central characteristics of how the four companies have implemented and applied RD are presented in summarised form in Table 2 below. 


\begin{tabular}{|c|c|c|c|c|}
\hline & MED & DEF & AERO & AUTO \\
\hline$\stackrel{2}{3}$ & $\begin{array}{l}\text { - Delays in late design } \\
\text { stages } \\
\text { - Shorter and more } \\
\text { predictable lead-time. }\end{array}$ & $\begin{array}{l}\text { - Internal cost of poor quality } \\
\text { - Resources tied up in control } \\
\text { and inspection. }\end{array}$ & $\begin{array}{l}\text { Cost of Non-Quality: } \\
\text { - } \quad \begin{array}{l}\text { Expensive "in service" } \\
\text { changes }\end{array} \\
\text { - } \begin{array}{l}\text { Cost of redesign due to } \\
\text { validation procedures. }\end{array}\end{array}$ & $\begin{array}{l}\text { Cost of Non-Quality: } \\
\text { - Avoid failures in market } \\
\text { - Maintain brand reputation. }\end{array}$ \\
\hline$\stackrel{3}{\varrho}$ & $\begin{array}{l}\text { - Defined roles and } \\
\text { responsibilities } \\
\text { - Robustness Cockpit with } 6 \\
\text { KPI's and requirements. }\end{array}$ & $\begin{array}{l}\text { - Gradual implementation of } \\
\text { Six Sigma and DFSS- } \\
\text { practices } \\
\text { - Defined System Engineer } \\
\text { role. }\end{array}$ & $\begin{array}{l}\text { - Training of engineers + chief } \\
\text { design engineers } \\
\text { - Certification scheme with } \\
\text { robustness. }\end{array}$ & $\begin{array}{l}\text { - Toolbox of 15+ RD tools } \\
\text { - Training and coaching (after } \\
\text { failed attempt using external } \\
\text { trainers). }\end{array}$ \\
\hline 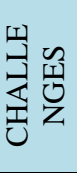 & $\begin{array}{l}\text { - Resistance to change } \\
\text { - RD seen as an add-on to } \\
\text { existing development } \\
\text { activities. }\end{array}$ & $\begin{array}{l}\text { - Lacking adoption of RD- } \\
\text { tools and methods } \\
\text { - Visualising the usefulness of } \\
\text { DoE after to initial } \\
\text { unsuccessful use. }\end{array}$ & $\begin{array}{l}\text { - Different perception of the } \\
\text { novelty in the initiative } \\
\text { - The initial process towards } \\
\text { RD was over-formalised. }\end{array}$ & $\begin{array}{l}\text { - Unsuccessful 'tool-pushing' } \\
\text { by external consultants } \\
\text { - No acknowledgement of } \\
\text { need for change. }\end{array}$ \\
\hline 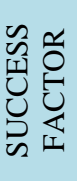 & $\begin{array}{l}\text { - Personal qualities and } \\
\text { competencies of chief / } \\
\text { lead engineers } \\
\text { • Coaching and support of } \\
\text { lead engineers. }\end{array}$ & $\begin{array}{l}\text { - Gradual implementation of } \\
\text { Six Sigma practice } \\
\text { Consistency in definitions of } \\
\text { framework. }\end{array}$ & $\begin{array}{l}\text { - Training and courses focus } \\
\text { on chief design engineers } \\
\text { - Having tools that are used on } \\
\text { daily basis. }\end{array}$ & $\begin{array}{l}\text { - Engagement and training of } \\
\text { middle management } \\
\text { - Transition from external } \\
\text { "tool-pushers" to internally } \\
\text { driven processes. }\end{array}$ \\
\hline 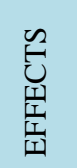 & $\begin{array}{l}\text { - Guidance on how to } \\
\text { develop good designs } \\
\text { - Increased transparency for } \\
\text { management. }\end{array}$ & $\begin{array}{l}\text { - Cross-functional } \\
\text { collaboration } \\
\text { - Design reviews increased } \\
\text { insight in design features. }\end{array}$ & $\begin{array}{l}\text { - More insight into their own } \\
\text { design \& understanding of } \\
\text { the product behaviour } \\
\text { - Saved time in PD-process. }\end{array}$ & $\begin{array}{l}\text { - Stronger focus on knowledge } \\
\text { and facts } \\
\text { - Increased understanding of } \\
\text { the root causes of failures. }\end{array}$ \\
\hline
\end{tabular}

Table 2 - Overview of the main findings from the interviews with the 4 case companies.

\subsection{Motivation for applying Robust Design}

We looked at the companies' motivation to work with RD and noticed that all manufacture products where reliability is a key feature. Product failures lead to considerable losses for the users of the products, either directly in the form of a health hazard for the user (MED) or the operator (DEF) or indirectly in the form of 'down time' of the product, which means that the truck (AUTO) or airplane (AERO) is taken out of service and cannot create value during this period. Another observation is that the companies' production volumes range from 'hundreds' to 'hundred millions', indicating that $\mathrm{RD}$ can be relevant for both small and large scale production. This contradicts the perception that the authors meet in industry, where it is often stated, that RD is only relevant for high volume production. It can be argued that a common characteristic of the companies' products is that they have high complexity and/or high performance requirements, indicating that $\mathrm{RD}$ is especially relevant for this type of products, but it is beyond the scope of this paper to elaborate on this observation. 
On the motivation for implementing

$\mathrm{RD}$, the companies gave two main

answers: i) Reduction of in-market

failures and ii) Reduction of

development lead-time and delays

during ramp-up. AUTO stated that:

"You have some failures occurring

hundreds or thousands of times. These

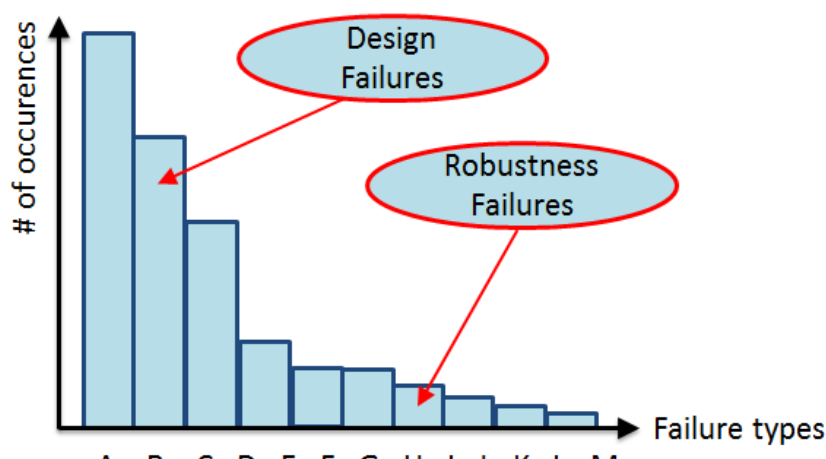

A B C D E F G H I J K L M

Figure 2. Graphical display of AUTO’s distinction between design- and sensitivity, based on the number of occurrences of the failure.

are design failures. But other failures occurring only a few times are signs of lacking robustness" (see Fig. 2). Over the years, AUTO has succeeded in removing the design failures through other initiatives such as design reviews, design optimisation, field analysis, customer feedback, warranty claims, and testing, but still experienced a "tail" of failures that did not occur that often. RD was seen as the countermeasure to further reduce the "tail" of the failure-curve. The motivation for MED was "unexpected bumps on the road" in late development stages of projects. The lack of predictability in the project execution created challenges in project planning due to the many departments involved in the development projects. Furthermore, the market is very competitive, so delays in the launch of a product are damaging. AERO found their motivation in the avoidance of expensive "in service" changes when design features had to be modified or replaced after customer deliveries. AERO was also motivated by the direct costs of non-quality, mainly via assessment and processing of concessions and quality plans. They wanted to reduce the extent of redesign, due to the costly “recertification and airworthiness procedures”. DEF reported motivation to reduce the amount of resources spent on internal quality assurance, to lower the inspection demand and to secure a less marginal design even for products exposed to extreme environmental demands (temperature etc.). 
Summing up, the motivation for applying RD was to reduce the cost of non-quality, but depending on the type of industry and product, the cost can take different forms (organisational turbulence, loss of brand value, cost of redesigning, cost of re-validation, etc.).

\subsection{How Robust Design was implemented}

Implementing new methods in an organisation will typically involve changes in roles, processes, and methods, which again requires training and on-going coaching. The four case companies have touched upon all of these aspects by offering training to their engineers and also to some extent to managers. The extent of formal training was typically: MED 5-8 days, AERO approx. 5 days, AUTO several days and at DEF the extensive training on Six Sigma was expanded towards RD. For all companies, continuous informal training from internal consultants was also given. An interesting point here is the apparent need to include middle management and the technical project managers in this training. AUTO pointed out the difference between a manager being "aware to and not opposing" a given method, and being “an expert himself”. The point being that the "pull” from management to use RD only comes when the manager is competent in the field. A similar experience was observed in AERO, where requests for internal RD coaching were limited, until the chief design engineers (which is the equivalent of a lead engineer in e.g. MED) went through a training course, after which, training requests saw a significant increase. It seems that - at least in the beginning - the application of RD methods did not come naturally, and if the immediate manager does not fully understand and know the methods, the engineers are not required to use them.

Another common trait has been the introduction of 'roles and responsibilities'. MED emphasises the appointment of a chief engineer with credibility in the organisation as one of the success factors and also mentions how they have worked to make the role of the lead engineers distinct and powerful, such that it is regarded with respect and honour. Besides this, there is still a central competence centre that can assist the projects with difficult analyses. 
AERO have installed an internal belting system, with green and black belts, thereby creating a clear hierarchy of facilitation experts. DEF has a less formal group of experts. However, AUTO has a dedicated group of project facilitators that help the project teams with making strategies for the reduction of performance variation.

There is a noticeable difference in how 'strict' the RD process is applied in the four companies. In DEF, RD is primarily based around structured design reviews, with a special focus on variation and tolerances, combined with a more cross-functional approach, where several departments are involved. AUTO and AERO provide a Robust Design-toolbox from which the engineers can choose from a range of tools and methods. At the gate-review, the engineers will be asked which RD aspects they have considered and which strategy or method they have applied to ensure robustness, but are not as such required to use specific methods. MED has a stricter format, where the gate-review involves the presentation of a Robustness Cockpit, with current values of 6 KPI's, indicating the robustness of the product. The KPIvalues are evaluated against specific target values in order to decide whether the product should pass the gate and move on to the next design stage.

Summing up, there is a common core in all four companies involving formal and informal training combined with specific roles and responsibilities, but the actual application of RD is quite different.

\subsection{Barriers against Robust Design implementation}

The companies reported to have experienced anything form large to very minor barriers on the implementation of Robust Design. Within MED some resistance could be traced back to a general resistance against change and a perception among the engineers that RD was an additional activity within product development, rather than an integrated way of working. A similar perception was identified within AERO, although this ranged from RD being 
perceived as a "science project" to "just good practice". Also, some tools were applied wrongly in the beginning, because there was a perception that the full suite of tools should be used, rather than just the relevant ones. AERO experienced as stated by the RD Manager "people coming out of a full-day QFD-session having created a 30x30 matrix and not wanting to ever apply RD again”. Within AERO, there was also an awareness to avoid "overformalisation of the RD Process" because such a process being governed and controlled by "review panels and charters" would have been a barrier for the application of RD. Within DEF, few direct barriers were experienced on the initiative as such however the company had experienced some barriers against applying powerful RD tools such as Design of Experiments (DoE). One of the barriers to applying DoE was seen in earlier unsuccessful attempts of application where no noticeable positive effect could be reported. AUTO had held a specific focus on RD for a decade and had adapted its approach for implementation on experiences from the early stages. An early attempt on implementing RD faced barriers as it was perceived among the engineers as "tool pushing” by external consultants, at this stage they also found barriers in the low commitment on the initiative among middle managers.

\subsection{Success factors for implementation of Robust Design}

Any good initiative is useless unless it gets accepted and applied by the organisation. Therefore we describe the companies' statements on success factors for implementing Robust Design. Where the first attempt of tool-pushing in AUTO was evaluated as a failed attempt (Azadeh Fazl Mashhadi et al. 2012) they drew lessons from it and adapted the approach. The success factor in the "second stage" of Robust Design-implementation was found in a much stronger engagement of the middle management level, the use of a learning alliances (Azadeh Fazl Mashhadi et al. 2013), a broader training regime, and the explicit implementation into a unified global development process across several sites worldwide. AERO reported that their thorough training was one of their success factors. They had established a "belt-system" 
similar to the known Six Sigma belt system (Aboelmaged 2010) of acknowledging formal skills and training. They pointed out that even deeper training of chief design engineers had contributed to secure that the RD tools were used on daily basis. The design process at AERO promoted the encouragement to apply tools "appropriately". So, no demand on toolapplications was made but rather suggestions of use were made and a RD toolbox was provided. At DEF one of the success factors was that the name of the product development framework was kept consistent. They had for more than a decade focused on Six Sigma and gradually reshaped the initiative to DFSS within manufacturing and development. Increased organisational awareness on variation and the active use of collaborative design reviews were reported. The reviews provided an arena to exchange critical objections on design issues related to lacking robustness and threatening sources of noise. The review was led by the systems engineer who was given a particular responsibility due to her outstanding technical and human skills, which made the review an arena to debate a certain design feature by chosen experts. MED pointed out the appointment of a chief engineer (overall technical responsible for all projects) with the right combination of technical and "people” skills, combined with an internal credibility, as a cornerstone for the successful implementation of RD. Furthermore, MED have seen that, "especially the lead engineers have undergone a fantastic development, driven by our internal Competence Centre and the external consultants, that has strengthened and changed the organisation”.

Summing up, the success factors of the four companies comprise several elements of training and roles, including training of middle management to create pull, defining a RD process with a balanced use of tools and methods that fits the organisation and working culture, and careful selection of RD ambassadors in the role of lead/chief engineers. 


\subsection{Effects on adapting Robust design}

All companies state that the aim of robust design is to improve their products. Yet different arguments were used. Some used the perspective of customer satisfaction, some argued on spending less internal resources, some were strongly focused on robustness as an aid to reduce risk, and others argued that the focus on robustness gave better insight into the product behaviour based on an increased focus on fact-based decisions. In particular MED pointed out the effect of improved guidance on how to develop good designs. This was achieved through the development and use of simple customised metrics providing engineers with an indication of the robustness of a given interface, at the point of design. The metrics are summed up in the so-called robustness cockpit, which according to the Senior Vice President "provides increased transparency and collaboration for the project and management teams”. The result has been that "the large majority of projects in the portfolio are now executed at the right costs and with the right feature set'. These indicators on robustness have been so successfully implemented that the Senior VP said “implementing Robust Design is the best decision I've ever made. It allows me to sleep well at night, knowing the status of all projects”. AERO named overall saved time in the Product Development-process as one of the main effects in addition to a deeper and increased insight into their own design, giving a better understanding of the product behaviour when exposed for noise. AUTO on the other hand chose to point out the main effect to be a stronger focus on "knowledge and facts as opposed to gut-feeling and tradition". One additional effect was the increased understanding of the root causes of failures, which had contributed to an additional reduction of undesired failures in the market. Effects observed at DEF included an improved cross-functional collaboration, practicing design reviews led by assigned systems engineers demanding clear statements on technological maturity throughout the development. None of the companies presented hard 
data documenting the effects of applying RD, but they generally had a "feeling" that the resources spent on $\mathrm{RD}$ provided value.

\section{5-Discussion}

The interview findings and subsequent data analysis revealed similarities and differences related to the RD implementation. All four companies had a similar 'core' of activities related to training and roles \& responsibilities; but used different approaches in other areas, here defined as four different archetypes of RD.

\subsection{Similarities in Training, Roles and Responsibilities.}

Table 3 summarises the ‘core’ of Robust Design- training, roles and responsibilities.

\begin{tabular}{|l|l|l|l|l|}
\hline \multicolumn{1}{|c|}{ RD Approach } & \multicolumn{1}{|c|}{ MED } & \multicolumn{1}{c|}{ DEF } & \multicolumn{1}{c|}{ AERO } & \multicolumn{1}{c|}{ AUTO } \\
\hline Training & $\begin{array}{l}\text { Formalised training } \\
\text { and substantial } \\
\text { ongoing coaching } \\
\text { from comp. centre. }\end{array}$ & $\begin{array}{l}\text { Formalized training } \\
\text { on handling variation } \\
\text { through extended Six } \\
\text { Sigma initiatives } \\
\text { moved upstream } \\
\text { towards RD. }\end{array}$ & $\begin{array}{l}\text { Formalised training + } \\
\text { substantial ongoing } \\
\text { coaching from comp. } \\
\text { centre. }\end{array}$ & $\begin{array}{l}\text { Formalised training + } \\
\text { substantial ongoing } \\
\text { coaching from comp. } \\
\text { centre. }\end{array}$ \\
\hline $\begin{array}{l}\text { Roles and } \\
\text { responsibilities }\end{array}$ & $\begin{array}{l}\text { Lead engineer on } \\
\text { each project plus an } \\
\text { overall chief engineer } \\
\text { with power to stop } \\
\text { projects. } \\
\text { Competence Centre } \\
\text { with experts within } \\
\text { each KPI. Allowance } \\
\text { to pass gates. }\end{array}$ & $\begin{array}{l}\text { Project leader and } \\
\text { Systems experienced } \\
\text { promote sharing } \\
\text { product/process } \\
\text { insight at all } \\
\text { organisational levels } \\
\text { continuously. }\end{array}$ & $\begin{array}{l}\text { Chief design engineer } \\
\text { on each project. } \\
\text { Green and Black } \\
\text { Belts as internal RD } \\
\text { consultants. }\end{array}$ & $\begin{array}{l}\text { Many roles. Quality } \\
\text { Manager, Knowledge } \\
\text { Manager, Gate } \\
\text { Auditor. Internal } \\
\text { coaching, allowance } \\
\text { to pass gates, etc. }\end{array}$ \\
\hline
\end{tabular}

Table 3 Similarities in Training, Roles and Responsibilities.

Since all four companies have a very similar approach in terms of training and roles, it can be argued that this approach constitutes a best-practice for a RD implementation. Hence, organisations considering to implement RD should include formal training for engineers and middle management (including lead and chief engineers), supplemented by informal and ongoing training. Furthermore, formalised and respected roles such as lead-, chief- and 
system-engineers should be developed, along with well-defined responsibilities regarding project governance, proper use of methods, and execution of design reviews.

\subsection{Differences in Process, Gate reviews and Tools}

Table 4 summarises the differences between the companies.

\begin{tabular}{|c|c|c|c|c|}
\hline RD Approach & MED & DEF & AERO & AUTO \\
\hline Process & $\begin{array}{l}\text { Development Manual. } \\
\text { Robustness Challenge } \\
\text { prior to every } \\
\text { milestone, where } \\
\text { cockpit with metrics } \\
\text { is presented. }\end{array}$ & $\begin{array}{l}\text { Design for Six Sigma } \\
\text { reviews with a } \\
\text { particular emphasis } \\
\text { on the selection of } \\
\text { robust design / } \\
\text { process- solutions. }\end{array}$ & $\begin{array}{l}\text { Loose process and } \\
\text { intentional lack of } \\
\text { KPI's. Instead a large } \\
\text { tool suite offered } \\
\text { along with guidance. } \\
\text { Formalised training, } \\
\text { but informal } \\
\text { application. }\end{array}$ & $\begin{array}{l}\text { Global Development } \\
\text { Process demanding } \\
\text { that strategies are } \\
\text { defined for dealing } \\
\text { with variations. }\end{array}$ \\
\hline Gate reviews & $\begin{array}{l}\text { Clear targets for gate } \\
\text { for every KPI. }\end{array}$ & \begin{tabular}{|l|} 
Defined Reviews \\
(Systems- / \\
Preliminary- / Critical \\
-. / Final Design) with \\
attention to robustness
\end{tabular} & $\begin{array}{l}\text { Projects given } \\
\text { pass/fail question: } \\
\text { How do you plan to } \\
\text { use RD tools in the } \\
\text { project? }\end{array}$ & $\begin{array}{l}\text { Projects asked about } \\
\text { strategy for dealing } \\
\text { with variation. }\end{array}$ \\
\hline Tools & $\begin{array}{l}6 \text { custom KPI's. Very } \\
\text { limited use of } \\
\text { traditional RD } \\
\text { toolbox }\end{array}$ & \begin{tabular}{|l|} 
Wide use of SPC \\
within manufacturing, \\
designers are \\
encouraged to use \\
SPC-viewers and to \\
design for robustness.
\end{tabular} & $\begin{array}{l}\text { Extensive use of } \\
\text { traditional RD } \\
\text { toolbox }\end{array}$ & $\begin{array}{l}\text { Use of traditional RD } \\
\text { toolbox alongside } \\
\text { customised methods } \\
\text { and tools. }\end{array}$ \\
\hline
\end{tabular}

Table 4 Differences in Process, Gate reviews and Tools

a) At MED Robust Design was implemented in a formalised manner in the "Development Manual” which also described the formal RD gate requirements. The established "Robustness Cockpit” with six KPI’s and target requirements directly linked to RD-activities secured continuous management attention and the ability for managers to judge the robustness maturity on ongoing projects. Altogether the successful implementation at MED is partly due to massive top-management pull and the ongoing coaching from their Competence Centre as well as an organisational culture based on compliance with company procedures. The reason 
for applying this approach was the need for a common and objective way to give a leading indication of the robustness of the product, as early as possible.

b) At DEF we noticed a less tool-based approach on RD where the particular strengths were seen in creating a common design understanding in DFSS reviews. This company also showed barriers on implementing tools and methods such as DoE within the company. Reasons why this company adapted this approach is seen in its medium company size, its colocated premises with development and manufacturing, the strong local connection with a very stable workforce and the extreme demands to the products' performance which can results in a risk of products lacking robustness. In order to prevent this, sharing of design understanding similar to Poggenpohl (2004) gained importance and attention.

c) Within AERO we noticed that the use of a well-defined toolbox of more than 40 RD-tools was formalised and requested by management in a stage-gate process, similar to Cooper and Kleinschmidt (2007) where management explicitly questioned the use of RD-tools, and so this was a formal requirement to pass the gates. They further saw their success in extensive training, courses and tools that were used on a daily basis. The toolbox was designed so that it not only described the theoretical side of the tool, but provided the user with suggestions on how this tool could be applied from a design context known by the employee, as also shown by (Costa et al. (2006)). This company reported that the positive effects of RD were a stronger and deeper insight into its own design and understanding of product behaviour which overall saved time in the Product Development-project. Altogether it appears that company AERO was not fully successful on implementing RD until their project chief design engineers went for training. This training created a 'pull' within the organisation that served as leverage for further organizational development on RD-practice. 
d) At company AUTO earlier attempts had shown negative effects of "tool-pushing" by consultants with an exaggerated focus on the statistical side of RD, the archetype now based further application of RD as an integrated part of a Lean initiative, just as Matthias Kreimeyer and Lindemann (2011) promotes an integrated perspective. This archetype sees the commitment and training of middle management in addition to employee training and top management support as crucial for making the workmode truly integrated. It eliminated the undesired perception of a "RD-campaign”, by adding "softer" values related to collaboration and visualisation on top of the already known technical aspects of the company. To summarise; company AUTO had carried out several "roll-outs" of RD initiatives with different approaches. They later underlined the need for middle management to gain deep knowledge on RD with the motto: "They must know it to require it".

\subsection{Four robust design archetypes}

Based on the results, we suggest and label four different approaches applied in the companies - called Robust Design Archetypes: The (i) Metrics based (ii) Collaborative approach, (iii) Formalised training scheme and (iv) Integrated approach. The metrics based approach was seen in company MED. The collaborative archetype on RD is observed in the company DEF. The formalised archetype on RD was seen in company AERO. The integrated approach on RD was shaped in AUTO over years of adapted training approaches.

\begin{tabular}{|l|c|c|c|c|}
\hline Company & MED & DEF & AERO & AUTO \\
\hline RD Archetype & Metrics based & Collaborative & Formalised & Integrated \\
\hline
\end{tabular}

Table 5 - Four identified archetypes of Robust Design practice

This research has yielded empirical insight into industrial practice on how RD is implemented and "lived" within industry. It is important to notice the fact that product development is a clearly context dependent activity and that "the universal best practice” for applying a given 
initiative probably cannot be prescribed. As researchers we also see the risk that these categories represent a potential (over-) simplification that does not cover all aspects of the initiatives. Whether adding additional companies to the case would have added further archetypes is a legitimate question that cannot be answered with an absolute statement prior to researching it. We are however confident that there is an upper limit on how "fine-meshed" categories still make sense. The proposed archetypes should therefore be seen as a guide and a potential first step towards an improved mapping-tool for industrial Robust Design-practice. These archetypes are therefore not to be understood to mutually exclude each other.

It is seen that the approaches are quite similar in terms of training and roles \& responsibilities, whereas they differ substantially in terms of process, gate reviews and tools. It is also worth noticing that especially MED and AUTO have extended the existing RD toolbox even further and have developed new methods and KPI's which are not described in literature, whereas the two others to a larger degree have taken the existing RD toolbox containing e.g. DoE and transfer functions and made it part of their development process. As a final point, it is interesting that none of the companies could make a clear statement on the costs and effects of implementing RD. While there is no good reason for not making an estimate on the cost of implementing $\mathrm{RD}$, the benefits are more complicated to estimate. One reason is that it is difficult to quantify the cost of non-quality in terms of e.g. loss of brand value. Furthermore, it is extremely challenging to document the effect of error prevention - how does one know which of the many design improvements due to RD activities would have otherwise become a costly failure further down the line? This is most likely an inherent weakness in establishing a well-documented business case for the implementation of RD.

\section{6-Conclusion}


Robustly designed products are insensitive to variation and provide the desired functional performance in spite of variations in use, deterioration etc. Implementing and using robust design principles is reported to be challenging in the industrial product development context in spite its rich theoretical body of literature. In this empirical paper based on a series of interviews among "best practice” companies on $\mathrm{RD}$, we identify that the cost of non-quality is a common motivation for implementing it. We further identify industrial differences on RD and suggest four possible archetypes for implementing and applying it - consisting of a common core consisting of training and formalised roles and responsibilities, supplemented by either a i) Metrics based approach ii) Collaborative, iii) Formalised, or iv) Integrated approach. We have outlined the experienced challenges, barriers and success factors of each approach, which paves the way for a potential assessment tool to determine which strategy will work best for a given company. This is valuable to organisations considering implementing RD, because they can gather inspiration from the description of four successful approaches and decide which one best suits their needs, based on their own motivation, organisational style, available resources and wanted effects.

\section{Further work}

As to an outlook, we see a potential for further research in consolidating the different Robust Design approaches presented in this paper into a generic RD Process with a set of relevant tools and methods for each design stage. Furthermore, there is a potential for developing a “Robust Design Maturity Model” to measure the maturity of an organisation in terms of RD. Finally, there is a potential for looking into how to link the generic process with the maturity model, so that it is possible to configure an optimal RD approach for any given company, depending on the context of their organisation, market, product, etc.

\section{Acknowledgements}


The authors would like to thank the four participating companies for their openness and furthermore would like to thank Valcon A/S and Nammo Raufoss AS for their contributions to the research projects.

\section{References}

Aboelmaged, Mohamed Gamal (2010), 'Six Sigma quality: a structured review and implications for future research', International Journal of Quality \& Reliability Management, 27 (3), 269.

Arnèr, Magnus (2014), Statistical Robust Design: An Industrial Perspective (March 2014 edn.: Wiley).

Arvidsson, Martin and Gremyr, Ida (2008), 'Principles of robust design methodology', Quality and Reliability Engineering International, 24 (1), 23-35.

Arvidsson, Martin, Gremyr, Ida, and Hasenkamp, Torben (2006), 'An operationalization of robust design methodology', (Chalmers University of Technology; Lund, Helsingborg: Lund University, Campus Helsingborg).

Banduelas, Richardo and Anthony, Jiju (2003), 'Going from Six Sigma to Design for Six Sigma: an explanatory study using analytic hierarchy process', The TQM Magazine, 15 (5), 334-44.

Bergman, Bo, et al. (2009), Robust Design Methodology for Reliability: Exploring the Effects of Variation and Uncertainty (Wiley-Blackwell) 214.

Bergquist, Bjarne and Albing, Malin (2006), 'Statistical Methods - Does Anyone Really Use Them?', Total Quality Management \& Business Excellence, 17 (8), 961-72.

Beyer, Hans-Georg and Sendhoff, Bernhard (2007), 'Robust optimization - A comprehensive survey', Computer Methods in Applied Mechanics and Engineering, 196 (33-34), 3190-218.

Box, George E. P. and Wilson, K.B. (1951), 'On the Experimental Attainment of Optimum Conditions', Journal of the Royal Statistical Society, B, 23, 1-45.

Calvo-Mora, Arturo, et al. (2013), 'The relationships between soft-hard TQM factors and key business results', International Journal of Operations \& Production Management, 34 (1), 115-43.

Cooper, Robert G and Kleinschmidt, Elko J. (2007), 'Winning Businesses in Product Development: The Critical Success Factors', Research-Technology Management, 50, 52-66.

Costa, Nuno R. P., Pires, António R., and Ribeiro, Celma O. (2006), 'Guidelines to help practitioners of design of experiments', The TQM Magazine, 18 (4), 386-99.

Davis, T. P. (2006), 'Science, engineering, and statistics: Research Articles', Appl. Stoch. Model. Bus. Ind., 22 (5\&ndash;6), 401-30.

Eifler, Tobias, Ebro, Martin, and Howard, Thomas J. (2013), 'A classification of the industrial relevance of robust design methods', in Udo Lindemann, et al. (eds.), International Conference on Engineering Design (ICED13), Design for Harmonies (DS 75-9: Proceedings of the 19th International Conference on Engineering Design, Vol.9: Design Methods and Tools,; Seoul, Korea, 19-22.08.2013), 427-36.

Ericsson, Evelina, et al. (2009), 'DFSS - evolution or revolution? A study of critical effects related to successful implementation of DFSS, ' Proceedings of ICQSS conference 2009, (Verona, Italy). 
Forslund, Karin and Söderberg, Rikard (2010), 'Effects of Geometric Variation on Perceived Quality', Product Lifecycle Management (John Wiley \& Sons, Inc.), 503-19.

Frankenberger, Eckart, Badke-Schaub, Petra, and Birkhofer, Herbert (1997), Designers - The key to successful product development (London: Springer-Verlag London Limited).

Goh, T. N. (1993), 'Taguchi Methods: Some technical, cultural and pedagogical perspectives', Quality and Reliability Engineering International, 9 (3), 185-202.

Gremyr, Ida (2005b), 'Robust Design Methodology - A framework and supportive methods', (Chalmers University).

Gremyr, Ida, Arvidsson, Martin, and Johansson, Per (2003), 'Robust Design Methodology: Status in the Swedish Manufacturing Industry', Quality and Reliability Engineering International, 19 (4), 285-93.

Gremyr, Ida and Hasenkamp, Torben (2011), 'Practices of robust design methodology in practice', The TQM Journal, 23 (1), 47-58.

Hasenkamp, Torben, Arvidsson, Martin, and Gremyr, Ida (2009), 'A review of practices for robust design methodology', Journal of Engineering Design, 20 (6), 645 - 57.

Hasenkamp, Torben, et al. (2007), 'Robust Design Methodology in a Generic Product Design Process', Total Quality Management \& Business Excellence, 18 (4), 351 - 62.

Hicks, Ben, et al. (2009), 'An intelligent design environment-overcoming fundamental barriers to realising a step change in design performance and innovation', proceedings of the 17th International Conference on Engineering Design (ICED'09): Design Society.

Johannesson, Pär, et al. (2013), 'A Robustness Approach to Reliability', Quality and Reliability Engineering International, 29 (1), 17-32.

Kreimeyer, M, et al. (2006), 'Die Konstruktionsmethodik im Wandel der Zeit - Ein Überblick zum 100sten Geburtstag von Prof. Wolf Rodenacker', Konstruktion, Oktober 10 - 2006 (10/2006), 3.

Kreimeyer, Matthias and Lindemann, Udo (2011), Complexity metrics in engineering design: managing the structure of design processes (Berlin, Heidelberg: Springer-Verlag Berlin Heidelberg) XIII, $403 \mathrm{~s}$.

Lai, Hsin-Hsi, et al. (2006), 'User-oriented design for the optimal combination on product design', International Journal of Production Economics, 100 (2), 253-67.

Leonard-Barton, Dorothy (1990), 'A Dual Methodology for Case Studies: Synergistic Use of a Longitudinal Single Site with Replicated Multiple Sites', Organization Science, 1 (3), 248-66.

Lindemann, Udo (2009), Methodische Entwicklung technischer Produkte - Methoden flexibel und situationsgerecht anwenden (Springer Verlag) 341.

Mashhadi, Azadeh Fazl, Alänge, Sverker, and Roos, Lars-Uno (2012), 'Introducing robust design in product development: Learning from an initiative at Volvo', Total Quality Management \& Business Excellence, 23 (9-10), 1191-205.

Mashhadi, Azadeh Fazl , Alänge, Sverker, and Roos, Lars-Uno (2013), 'A learning alliance for robust design in product development: the case of Volvo 3P and Chalmers University of Technology', Total Quality Management \& Business Excellence, 1-18.

Matthiassen, Benny (1997), 'Design for Robustness and Reliability - Improving the Quality Consciousness in Endineering Design', (Technical University of Denmark).

Murphy, Terrence E., Tsui, Kwok-Leung, and Allen, Janet K. (2005), 'A review of robust design methods for multiple responses', Research in Engineering Design, 15 (4), 20115.

Myers, Raymond H., Khuri, André I., and Carter, Walter H. (1989), 'Response Surface Methodology: 1966-1988', Technometrics, 31 (2), 137-57. 
Myers, Raymond H., et al. (2004), 'Response Surface Methodology: A Retrospective and Literature Survey', Journal of Quality Technology, 36 (1), 53.

Nair, Vijayan N., et al. (1992), 'Taguchi's Parameter Design: A Panel Discussion', Technometrics, 34 (2), 127-61.

Park, G, et al. (2006), 'Robust design: An overview', AIAA Journal, 44, 181-91.

Parsley, A., et al. (2013), 'The use of a systems engineering process guide to accelerate improvement in systems engineering application and expertise', Systems Conference (SysCon), 2013 IEEE International, 718-24.

Pentland, Alex (2012), 'The new science of building great teams', Harvard Business Review, April 2012, 10.

Pinedo-Cuenca, Ruben, Pablo Gonzalez, Olalla, and Setijono, Djoko (2012), 'Linking Six Sigma's critical success/hindering factors and organizational change (development)', International Journal of Lean Six Sigma, 3 (4), 284-98.

Poggenpohl, Sharon Helmer (2004), 'Practising collaboration in design', Visible Language, 38 (2), 138-57.

Reinertsen, Donald G. (2009), Flow; The principles of product development - Second generation product development (Celeritas Publishing).

Richtnér, Anders and Åhlström, Pär (2010a), 'Top management control and knowledge creation in new product development', International Journal of Operations \& Production Management, 30 (10), 1006-31.

Robson, Ian (2005), 'Implementing a performance measurement system capable of creating a culture of high performance', International Journal of Productivity and Performance Management, 54 (2), 137-45.

Saitoh, K., et al. (2003a), 'A study about how to implement quality engineering in research and development (Part 1)', Journal of Quality Engineering Society, 11 (2003a), 10007.

Saitoh, K., et al. (2003b), 'A study about how to implement quality engineering in research and development (Part 2)', Journal of Quality Engineering Society, 11 (2003b), 64-69.

Taguchi, Genichi (1986), Introduction to Quality Engineering - Designing Quality into Products and Processes (Tokyo: Asian Productivity Organization).

Thornton, Anna C (2004), Variation risk management: focusing quality improvements in product development and production (Wiley Hoboken).

Thornton, Anna C., Donnelly, Stephen, and Ertan, Basak (2000), 'More than Just Robust Design: Why Product Development Organizations Still Contend with Variation and its Impact on Quality', Research in Engineering Design, 12 (3), 127-43.

Tjora, Aksel Hagen (2012), Kvalitative forskningsmetoder i praksis (Oslo: Gyldendal akademisk) 246 s. : ill.

Yin, Robert K. (2003), Applications of case study research (Thousand Oaks, Calif.: Sage Publications) XVIII, $173 \mathrm{~s}$. 


\section{Appendix}

\section{A comprehensive listing of the main findings summed up in Table 2.}

\begin{tabular}{|c|c|c|c|c|}
\hline & DEVICE & DEFENSE & AEROSPACE & AUTOMOTIVE \\
\hline$\sum_{3}^{2}$ & $\begin{array}{l}\text { - Delays in late design stages. } \\
\text { - Shorter and more predictable } \\
\text { leadtime. }\end{array}$ & $\begin{array}{l}\text { - Internal cost of poor quality } \\
\text { (resources tied up in control } \\
\text { and inspection). }\end{array}$ & $\begin{array}{l}\text { Cost of Non-Quality: } \\
\text { - Expensive "in service" } \\
\text { changes. } \\
\text { - Cost of redesign due to } \\
\text { rigorous approval and } \\
\text { validation procedures. }\end{array}$ & $\begin{array}{l}\text { Cost of Non-Quality: } \\
\text { - Avoid failures in market, to } \\
\text { maintain brand reputation. }\end{array}$ \\
\hline $\begin{array}{l}3 \\
0 \\
\text { II }\end{array}$ & $\begin{array}{l}\text { - Pilot projects } \\
\text { - Defined roles and } \\
\text { responsibilities } \\
\text { - Robustness Cockpit with } 6 \\
\text { KPI's and target } \\
\text { requirements } \\
\text { - Training and coaching of } \\
\text { engineers and lead engineers } \\
\text { - Updated Development } \\
\text { Manual with formal RD gate } \\
\text { requirements }\end{array}$ & $\begin{array}{l}\text { - Gradual implementation of } \\
\text { Six Sigma and DFSS- } \\
\text { practices } \\
\text { - Defined System Engineer } \\
\text { role } \\
\text { - Training of design and } \\
\text { manufacturing engineers } \\
\text { - Review Procedure }\end{array}$ & $\begin{array}{l}\text { - Training of engineers + chief } \\
\text { design engineers } \\
\text { - Certification scheme with } \\
\text { robustness belts (green + } \\
\text { black) } \\
\text { - Toolbox of } 40+\text { RD tools } \\
\text { - Stage-gate process that } \\
\text { explicitly questions the usage } \\
\text { of RD principles }\end{array}$ & $\begin{array}{l}\text { - Pilot projects } \\
\text { - Toolbox of } 15+\text { RD tools } \\
\text { - Training and coaching (after } \\
\text { failing attempt on using } \\
\text { external trainers) } \\
\text { - Updated Global } \\
\text { Development Process with } \\
\text { formalised RD gate } \\
\text { requirements (without metric } \\
\text { targets), }\end{array}$ \\
\hline 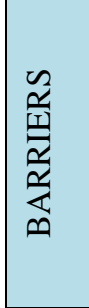 & $\begin{array}{l}\text { - Resistance to change } \\
\text { - RD seen as an add-on to } \\
\text { existing development } \\
\text { activities. }\end{array}$ & $\begin{array}{l}\text { - Lacking adoption of trained } \\
\text { RD-tools and methods (e.g. } \\
\text { DoE) after training. } \\
\text { - Visualizing the usefulness of } \\
\text { DoE posterior to initial } \\
\text { unsuccessful attempts of use. }\end{array}$ & $\begin{array}{l}\text { - Perceived by some as a } \\
\text { science project. } \\
\text { - By others regarded as “just } \\
\text { good practice” (two extremes } \\
\text { see above) } \\
\text { - The initial process towards } \\
\text { RD was over-formalized. }\end{array}$ & $\begin{array}{l}\text { - Unsuccessful ‘toolpushing’ } \\
\text { - No acknowledgement of } \\
\text { need for change. } \\
\text { - Poor integration into daily } \\
\text { activities } \\
\text { - Lack of statistical } \\
\text { knowledge. }\end{array}$ \\
\hline 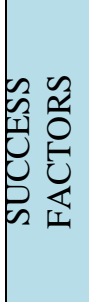 & $\begin{array}{l}\text { - Personal qualities and } \\
\text { competencies of chief / lead } \\
\text { engineers. } \\
\text { - Emphasising the importance } \\
\text { of Chief/lead-engineer roles } \\
\text { on decision making. } \\
\text { - Coaching and support of lead } \\
\text { engineers. }\end{array}$ & $\begin{array}{l}\text { - Gradual implementation of } \\
\text { Six Sigma practice over } \\
\text { time. } \\
\text { - Consistency in definitions of } \\
\text { framework (Six Sigma) } \\
\text { despite of development in its } \\
\text { content (added content). }\end{array}$ & $\begin{array}{l}\text { - Training and courses } \\
\text { - Having tools that are used on } \\
\text { daily basis. } \\
\text { - Training of chief design } \\
\text { engineers } \\
\text { - Encouragement to apply } \\
\text { tools "appropriately", no } \\
\text { demand but suggestions of } \\
\text { use/ provided toolbox. }\end{array}$ & $\begin{array}{l}\text { - Engagement and training of } \\
\text { middle management. } \\
\text { - Transition from using } \\
\text { external tool-pushers to } \\
\text { internally driven learning } \\
\text { processes. } \\
\text { - Improved ability to } \\
\text { communicate the importance } \\
\text { of RD internally. }\end{array}$ \\
\hline 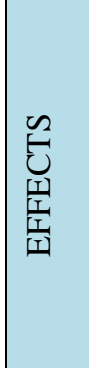 & $\begin{array}{l}\text { - Guidance on how to develop } \\
\text { good designs. } \\
\text { - Increased transparency for } \\
\text { management. } \\
\text { - Large majority of projects in } \\
\text { portfolio are executed at } \\
\text { right costs + right feature set. }\end{array}$ & $\begin{array}{l}\text { - Cross-functional } \\
\text { collaboration } \\
\text { - Design reviews led by } \\
\text { assigned systems engineer } \\
\text { demanding clear statements } \\
\text { on technological maturity. } \\
\text { - Increased insight in } \\
\text { parameter influence on } \\
\text { overall performance supports } \\
\text { targeted definition of safety } \\
\text { factors. . }\end{array}$ & $\begin{array}{l}\text { - More insight into their own } \\
\text { design (understanding of the } \\
\text { product behaviour as such). } \\
\text { - Saved time (overall in the } \\
\text { PD-process) }\end{array}$ & $\begin{array}{l}\text { - Stronger focus on knowledge } \\
\text { and facts (opposed to gut- } \\
\text { feeling and tradition). } \\
\text { - Increased understanding of } \\
\text { the root causes of failures. } \\
\text { - Reduction of undesired } \\
\text { failures in the market. }\end{array}$ \\
\hline$\sum_{\substack{1 \\
y}}^{\infty} \sum_{\substack{n \\
\sum}}^{\infty}$ & $\begin{array}{l}\text { - Earlier update of the product } \\
\text { development manual } \\
\text { - Harder push to also apply } \\
\text { RD in the early phase of } \\
\text { product development. }\end{array}$ & $\begin{array}{l}\text { - Daring to apply principles } \\
\text { earlier / in more projects at } \\
\text { the same time (faster roll- } \\
\text { out). } \\
\text { - Utilize knowledge potential } \\
\text { in gathered data from other } \\
\text { projects / manufacturing. }\end{array}$ & $\begin{array}{l}\text { - Having leading KPI's } \\
\text { - A better systems view and a } \\
\text { more top-down approach. }\end{array}$ & $\begin{array}{l}\text { - Further improve } \\
\text { communication to / among } \\
\text { engineers. } \\
\text { - Continue existing knowledge } \\
\text { sharing activities (homepage, } \\
\text { posters, workshops, } \\
\text { conferences, etc.) }\end{array}$ \\
\hline
\end{tabular}

Table 6 - Overview of the main findings from the interviews with the 4 case companies. 